\title{
Haemodynamic adaptation at rest and during exercise to long-term antihypertensive treatment with combination of beta-receptor blocking and vasodilator agent
}

\author{
Günter Koch \\ From the Department of Clinical Physiology, Central Hospital, Karlskrona, Sweden, and Department of \\ Physiology, Free University, Berlin, Germany (GFR)
}

Systemic and pulmonary haemodynamics were studied at rest in the supine and upright position, and during exercise in the sitting position at 75 and $150 \mathrm{Watt}$, in 13 hypertensive men aged $50 \cdot 8 \pm 8 \cdot 7$ years before and after 13 months treatment with oral oxprenolol (120 to $160 \mathrm{mg}$ t.i.d.) supplemented by oral hydrallazine (50 to $75 \mathrm{mg}$ t.i.d.) during the last 6 months. Pressures were recorded by means of catheters inserted percutaneously into the pulmonary and brachial artery; cardiac output was determined according to Fick.

Treatment resulted in a significant reduction of systemic systolic, diastolic, and mean pressures at rest in the supine position and during exercise, and of systolic pressures in the upright posture. Pulmonary systolic and mean pressures increased slightly at rest in the supine position and during exercise, and no changes occurred at rest in the upright position. The left ventricular filling pressure was unchanged at rest both in the supine and upright position; it increased slightly during exercise.

The haemodynamic changes by which systemic pressure was reduced were those typical of beta-adrenergic blockade: reduction of cardiac output resulting from a decrease of both heart rate and stroke volume, while the total systemic vascular resistance was unchanged at rest in the supine position but increased in the upright posture and during exercise. The $\mathrm{A}-\mathrm{V} \mathrm{O}_{2}$ difference increased remarkably.

This long-term observation again suggests that the acute haemodynamic effects of an antihypertensive regimen can be modified during long-term application. It did not give evidence of a readjustment of the vascular resistance occurring, at least not in the upright position and during exercise, as has been suggested for long-term beta-adrenergic blockade.

Adrenergic beta-receptor blocking agents have increasingly been used in the treatment of hypertensive disease during the past years (Prichard and Gillam, 1966, 1969; Dollery, Paterson, and Conolly, 1969; Johnsson et al., 1969; Werkö, 1971; Eisalo et al., 1974; Bengtsson, 1974; Hansson and Werkö, 1975, and others). Their blood pressure lowering action is associated with a fall in cardiac output; the systemic vascular resistance is initially not consistently affected (Sannerstedt, 1974), but may be reduced during prolonged treatment (Tarazi and Dustan, 1972).

Advanced stages of hypertension are associated with low cardiac output and increased systemic Received 19 May 1976. vascular resistance (Lund-Johansen, 1967). Because of their haemodynamic effects beta-receptor blocking agents evidently are not the drugs of choice from the physiological point of view in such conditions. On the other hand, peripheral vasodilators lower systemic blood pressure by decreasing the systemic vascular resistance (Åblad, 1963; Johnston, 1975; Zacest, 1975). However, the pressure decrease activates the homeostatic mechanism of the baroreceptors, thus causing an increase in heart rate and cardiac output. This secondary effect has in the past limited the usefulness of vasodilators as antihypertensive agents.

Studies in both the experimental animal (Brunner, Hedwall, and Meier, 1967) and man 
(Sannerstedt et al., 1971) have shown that the homeostatic reflex mechanism elicited by the vasodilator hydrallazine can be counteracted by simultaneous administration of a beta-receptor blocking agent; and several clinical trials have documented the beneficial effect of such combined treatment (Katila and Frick, 1970; Berglund and Hansson, 1971; Zacest, Gilmore, and Koch-Weser, 1972; Freeman and Knight, 1975).

However, in spite of the evident rationale for combined beta-receptor blocking and vasodilator treatment, at least in certain stages of the hypertensive disease, information concerning the haemodynamic effects of such therapy is extremely scanty. There appears to be but a single study of its acute effects (Sannerstedt et al., 1971), while there is no information regarding the haemodynamic adaptation to long-term treatment. The purpose of the present study was to provide such information. It is exclusively focused on the haemodynamic effects, while further clinical evaluations and renal effects will be reported elsewhere. The beta-receptor blocking and vasodilator agents used were oxprenolol (Trasicor) and hydrallazine (Apresoline), respectively. Oxprenolol was given alone during an average period of 7 months; thereafter hydrallazine was added, the combined treatment lasting another 6 months.

\section{Patients}

Sixteen hypertensive patients (15 men, one woman) who were referred to the department for investigation of cardiac and/or renal function gave their informed consent to this study; after taking part in the initial investigation, 3 of them, however, did not attend the follow-up examinations regularly and were withdrawn.

Thirteen male patients, mean age 50.8 $\pm 8 \cdot 7$, range 35.4 to $64 \cdot 2$ years, completed the entire trial. In 5 of them hypertension had been discovered recently and no treatment had been initiated: 8 of them had suffered from hypertension for between 5 and 12 years and had been receiving antihypertensive treatment. In all patients, however, antihypertensive therapy had been discontinued at least 6 weeks before the initial examination. Blood pressures when measured by the Riva-Rocci cuff method ranged between 155/105 and 210/120 $\mathrm{mmHg}$ at rest and between $210 / 115$ and $270 / 140$ $\mathrm{mmHg}$ during exercise. The clinical evaluation indicated that all had stage 1 to 2 essential hypertension using criteria described by the W.H.O. (1959); blood counts, serum electrolytes, serum creatinine, liver and renal function tests were normal. Fundoscopic examination revealed no
TABLE 1

\begin{tabular}{lcccc}
\hline & Mean & $S D$ & $\bar{D}$ & $\bar{D} \%$ \\
\hline Age (ys) & $50 \cdot 8$ & $8 \cdot 7$ & $1 \cdot 1$ & $2 \cdot 0$ \\
Weight (kg) & $83 \cdot 2$ & $8 \cdot 1$ & $2 \cdot 1 \star \star$ & $2 \cdot 5 \star \star$ \\
Blood volume (l) & $6 \cdot 5$ & $1 \cdot 1$ & $0 \cdot 7$ & $10 \cdot 8$ \\
Total Hb (g) & 908 & 166 & 21 & $2 \cdot 3$ \\
Heart volume (ml)t & 965 & 184 & 59 & $6 \cdot 1$ \\
\hline
\end{tabular}

Means and standard deviations (SD) of some anthropometric data before and their mean $(\bar{D})$ and percentage $(\bar{D} \%)$ changes after a 13-month period of treatment. Asterisks denote level of statistical significance: $\star \star=P<0.01$.

†Determined by Larsson and Kjellberg (1948).

abnormality in 5 subjects; 8 had non-exudative hypertensive changes, grade 1 to 2 of the KeithWagener-Barker scale. None had evidence of ischaemic heart disease as evaluated by exercise electrocardiogram (maximal work load 150 Watts in 7 and 200 Watts in 6 subjects) or of significant cardiac enlargement (mean relative heart volume $475 \pm 81$, range 370 to $635 \mathrm{ml} / \mathrm{m}^{2}$ body surface area). Chest $x$-ray films and spirometry gave no indication of lung disease. Some relevant anthropometric data including blood volume, heart volume, and total amount of haemoglobin are given in Table 1.

\section{Methods}

\section{General procedure}

The patients were studied with identical techniques and under identical conditions before and after treatment with the combination of oxprenolol plus hydrallazine.

The entire investigation programme comprised a complete clinical evaluation including blood and urine analysis, a chest $x$-ray film, spirometry, an exercise test with simultaneous electrocardiogram and blood pressure (cuff method) recording (Jacobsson et al., 1966), inulin- and PAH-clearance, determination of blood volume and renin activity, and the haemodynamic investigation.

The antihypertensive treatment aimed at reaching blood pressure levels at rest below $140 / 90 \mathrm{mmHg}$ when measured by the Riva Rocci method and during exercise at the highest load below 220/100 $\mathrm{mmHg}$. Therapy was started within 4 weeks after the initial series of examinations with $\mathbf{4 0} \mathrm{mg}$ t.i.d. of oral oxprenolol. This dose was gradually increased by increments of $40 \mathrm{mg}$ t.i.d. up to $160 \mathrm{mg}$ t.i.d. or until the maximal blood pressure lowering effect was attained. Mean duration of treatment with oxprenolol as the only drug was 7 months, all patients being on a total daily dose of 360 or $480 \mathrm{mg}$ oxprenolol at the end of this period.

After a new series of examinations comprising 
the above-mentioned tests but excluding the haemodynamic study, oral hydrallazine was added in an initial dose of $25 \mathrm{mg}$ t.i.d. and gradually increased to a maximum $75 \mathrm{mg}$ t.i.d. until the desired blood pressure level or the maximal pressure lowering effect was achieved. All patients were finally on a total daily dose of 150 or $225 \mathrm{mg}$ hydrallazine.

\section{Haemodynamic investigation}

Haemodynamics were studied at rest in the supine and in the upright position, and during exercise at two different work loads in the sitting position, on an electrically braked bicycle ergometer (Jacobsson et al., 1966). Both the orthostatic test and exercise on each work load lasted for 6 minutes. Work loads were $75\left(W_{1}\right)$ and $150 W_{\text {att }}\left(W_{2}\right)$, the higher one corresponding to about 70 to 80 per cent of the patient's maximal $\mathrm{O}_{2}$ uptake.

Having fasted overnight the patients came to the laboratory at about 8 a.m. Polyvinyl catheters were inserted percutaneously (Koch, 1971a) in a brachial artery (the same on both occasions) and in an antecubital vein; the tip of the venous catheter was then placed into the main pulmonary artery using a spiral guide wire and fluoroscopy; 20 minutes were allowed to elapse before measurements were started.

Blood pressures were recorded by means of an Elema 82 multichannel direct recorder using the Elema strain gauge transducers, together with the electrocardiogram. In the supine position the midaxillary line, and in the erect and sitting position the sternal angle were taken as zero pressure levels. Pressure recordings were taken after 4 minutes' standing and exercise, respectively.

Cardiac output was determined according to the direct Fick principle. Oxygen uptake was measured using the Douglas bag technique. Expired air was collected during 5 minutes at rest in the supine and during 3 minutes at rest in the erect posture and during exercise, starting 3 minutes after the onset of standing and exercise, respectively. Arterial and mixed venous blood samples were taken simultaneously during the collection of expired air.

The systemic (peripheral) vascular resistance (SVR) and the pulmonary vascular resistance (PVR) were calculated according to the equations:

$$
\begin{aligned}
& \mathrm{SVR}=\frac{\overline{\mathrm{P}}_{\mathrm{BA}}-\overline{\mathrm{P}}_{\mathrm{RA}}}{\mathrm{CO}} \text { and } \\
& \mathrm{PVR}=\frac{\overline{\mathrm{P}}_{\mathrm{PA}}-\overline{\mathbf{P}}_{\text {diast. PA }}}{\mathrm{CO}}
\end{aligned}
$$

where $\overline{\mathbf{P}}_{\mathrm{BA}}, \overline{\mathrm{P}}_{\mathrm{RA}}$, and $\overline{\mathrm{P}}_{\mathrm{PA}}$ are the mean pressures in the brachial artery, right atrium (resting value), and pulmonary artery, respectively, and $\overline{\mathbf{P}}_{\text {diast. }}$ PA is the diastolic pressure in the pulmonary artery. It is well established (Forsberg, 1971) that the pulmonary artery diastolic pressure reflects the pulmonary wedge pressure provided there is no significant rise in pulmonary vascular resistance.

\section{Blood and gas analyses}

The volume of expired air was measured in a gasometer, $\mathrm{O}_{2}$ and $\mathrm{CO}_{2}$ were determined according to Scholander (1947), the $\mathrm{O}_{2}$ saturation and the haemoglobin concentration with a spectrophotometric method (Holmgren and Pernow, 1959) using a Beckman $\mathrm{B}$ photometer; $\mathrm{pH}, \mathrm{PO}_{2}$, and $\mathrm{PCO}_{2}$ were determined with microelectrodes using Radiometer's PMH 72, lactic acid was determined enzymatically (Hohorst, 1963). Blood gas analyses were performed within 30 minutes after sampling. Methodological details, including the analytical accuracy, are given elsewhere (Koch, 1968).

\section{Statistical methods}

Current statistical methods were used for calculation of standard deviations (SD), mean differences $(\bar{D})$, and t-analyses (Snedecor, 1967). Comparison of data obtained before and after treatment was always based on paired samples.

\section{Results}

Mean values and standard deviations of some relevant haemodynamic measurements before the onset of treatment, as well as the changes observed after the combined oxprenolol-hydrallazine treatment, are given in Tables 2 and 3.

The pretreatment average systemic blood pressure was $159 / 88 \mathrm{mmHg}$, mean $117 \mathrm{mmHg}$, at rest in the supine, and $165 / 100 \mathrm{mmHg}$, mean $125 \mathrm{mmHg}$, in the upright position; it rose to $248 / 113 \mathrm{mmHg}$, mean $160 \mathrm{mmHg}$, during exercise $\left(\mathrm{W}_{2}\right)$. Treatment resulted in significantly lower blood pressure levels under all conditions, the effect being most pronounced during exercise and systolic pressures being most affected. Though the average diastolic and mean pressures during standing were about 10 per cent lower, this difference was just below the limit of statistical significance.

Blood pressures in the pulmonary circulation were within normal limits both before and after treatment; after treatment, however, they were slightly $(P<0.05$ to $P<0.001)$ higher during exercise and at rest in the supine position. The effect was most pronounced during exercise.

Heart rate was significantly lower after treatment 
TABLE 2

\begin{tabular}{|c|c|c|c|c|c|}
\hline & & Mean & $S D$ & $\bar{D}$ & $\bar{u} \%$ \\
\hline \multicolumn{6}{|l|}{ Brachial artery } \\
\hline & & 159 & 19 & $-23 \star \star \star$ & $-14 \cdot 6 \star \star \star$ \\
\hline \multirow{4}{*}{$\begin{array}{l}\text { Systolic pressure } \\
\quad(\mathrm{mmHg})\end{array}$} & & 165 & 24 & $-20 \star \star$ & $-12 \cdot 0 \star \star$ \\
\hline & & 205 & 27 & $-38 \star \star \star$ & $-18 \cdot 5^{\star \star \star}$ \\
\hline & & 248 & 33 & $-68 \star \star \star$ & $-27 \cdot 3 \star \star \star$ \\
\hline & & 88 & 10 & $-8^{\star}$ & $-8 \cdot 9 \star$ \\
\hline \multirow{4}{*}{$\begin{array}{l}\text { Diast. pressure } \\
\quad(\mathrm{mmHg})\end{array}$} & $\mathbf{O}$ & 100 & 15 & -9 & $-9 \cdot 2$ \\
\hline & $W_{1}$ & 102 & 12 & $-10 \star \star$ & $-10 \cdot 2^{\star \star}$ \\
\hline & & 113 & 16 & $-21^{\star \star \star}$ & $-18 \cdot 4 \star \star \star$ \\
\hline & & 117 & 13 & $-14^{\star \star}$ & $-12 \cdot 0 \star \star$ \\
\hline \multirow{3}{*}{$\begin{array}{l}\text { Mean pressure } \\
(\mathrm{mmHg})\end{array}$} & $\mathbf{O}$ & 125 & 18 & -12 & $-9 \cdot 7$ \\
\hline & $W_{1}$ & 141 & 15 & $-19 \star \star$ & $-13 \cdot 4 \star \star$ \\
\hline & $W_{2}$ & \multicolumn{3}{|c|}{ Pulmonary artery } & $-18 \cdot 4^{\star \star \star}$ \\
\hline Pulmonary artery & & 24 & 3 & $3 \star$ & $14 \cdot 2^{\star}$ \\
\hline \multirow{4}{*}{$\begin{array}{l}\text { Systolic pressure } \\
(\mathrm{mmHg})\end{array}$} & O & 22 & 5 & 1 & $3 \cdot 7$ \\
\hline & $W_{1}$ & 38 & 8 & $6 \star \star \star$ & $14 \cdot 5 \star \star \star$ \\
\hline & & 46 & 8 & $6 \star \star \star$ & $14 \cdot 2 \star \star$ \\
\hline & & 7 & 3 & 1 & $22 \cdot 1$ \\
\hline \multirow{4}{*}{$\begin{array}{l}\text { Diastolic pressure } \\
\quad(\mathrm{mmHg})\end{array}$} & O & 7 & 3 & 0 & $3 \cdot 1$ \\
\hline & $W_{1}$ & 12 & 5 & $4 \star \star$ & $36 \cdot 9 \star \star$ \\
\hline & & 14 & 6 & $7 \star \star \star$ & $51 \cdot 0 \star \star \star$ \\
\hline & $\mathbf{R}$ & 13 & 3 & $3 \star$ & $22 \cdot 7 \star$ \\
\hline \multirow{4}{*}{$\begin{array}{l}\text { Mean pressure } \\
(\mathrm{mmHg})\end{array}$} & 0 & 11 & 3 & 1 & $13 \cdot 0$ \\
\hline & $W_{1}$ & 21 & 6 & $7 \star \star \star$ & $34 \cdot 6 \star \star \star$ \\
\hline & & 28 & 7 & $8 \star \star \star \star$ & $28 \cdot 4 \star \star \star$ \\
\hline & & $14 \cdot 8$ & $3 \cdot 4$ & $3 \cdot 4$ & 23.0 \\
\hline \multirow{4}{*}{$\begin{array}{l}\text { Periph. vasc. resist } \\
(\mathrm{mmHg} / \mathrm{l} \text { per } \mathrm{min})\end{array}$} & O & $18 \cdot 4$ & $5 \cdot 8$ & $8 \cdot 3 \star$ & $45 \cdot 1$ * \\
\hline & $W_{1}$ & $8 \cdot 9$ & $2 \cdot 2$ & $4 \cdot 7 \star \star$ & $52 \cdot 8 \star \star$ \\
\hline & $W_{2}$ & $7 \cdot 4$ & $1 \cdot 1$ & $2 \cdot 6^{\star \star}$ & $35 \cdot 1 \star \star$ \\
\hline & & $0 \cdot 74$ & $0 \cdot 25$ & $0 \cdot 58 \star \star \star$ & $\star 78 \cdot 4^{\star \star \star}$ \\
\hline \multirow{3}{*}{$\begin{array}{l}\text { Pulm. vasc. resist. } \\
\text { (mmHg/1 per min) }\end{array}$} & $\mathrm{O}$ & 0.76 & 0.41 & $0.94 \star \star$ & $123 \cdot 7 \star \star$ \\
\hline & $W_{1}$ & 0.60 & $0 \cdot 15$ & $0 \cdot 87 \star \star \star$ & $\star 145 \cdot 0^{\star \star \star}$ \\
\hline & $W_{2}$ & 0.62 & $0 \cdot 19$ & $0.57^{\star \star \star}$ & $\star 91 \cdot 9 \star \star \star$ \\
\hline
\end{tabular}

Means and standard deviations (SD) of blood pressures and vascular resistances before and their mean (D) and percentage $(\overline{\mathrm{D}} \%)$ changes after 13 months of antihypertensive treatment at rest in the supine (R) and the upright (O) position and during exercise at two different work loads $\left(\mathbb{W}_{1}=75 \mathrm{~W}, \mathbb{W}_{2}=150 \mathrm{~W}\right)$. Asterisks denote level of statistical significance: ${ }^{\star}=\mathrm{P}<0.05, \star \star=\mathrm{P}<0.01, \star \star \star=\mathrm{P}<0.001$.

at rest in the upright position $(17 \%, \mathrm{P}<0.05)$ and during exercise $\left(18 \%\right.$ and $24 \%, \mathrm{P}<0.001$, at $\mathrm{W}_{1}$ and $\mathrm{W}_{2}$, respectively); it was on the average 8 beats lower in the supine position $(0.1>\mathbf{P}<0.05)$.

Both oxygen uptake $\left(\mathrm{V}_{2}\right)$ and minute ventilation $(\dot{V} E)$ were lower in the upright position after treatment $(P<0.05)$, the minute ventilation was also lower during $\mathrm{W}_{1}(\mathrm{P}<0.05)$.

Pretreatment cardiac output both at rest and during exercise was high $(8.7 \pm 1.91 / \mathrm{min}$ at rest and $21 \cdot 6 \pm 4 \cdot 0 \mathrm{l} / \mathrm{min}$ at $\mathrm{W}_{2}$ corresponding to an oxygen uptake of $2 \mathrm{l} / \mathrm{min}$ ) particularly when the patients' age is taken into account. Post-treatment cardiac outputs were significantly lower, the decrease ranging between 23 per cent at rest in the supine $P<0.01)$ and about 40 per cent in the erect
TABLE 3

\begin{tabular}{|c|c|c|c|c|c|}
\hline & & Mean & $S D$ & $\widetilde{D}$ & $\bar{D} \%$ \\
\hline & $\mathbf{R}$ & 71 & 12 & -8 & $-11 \cdot 3$ \\
\hline \multirow{4}{*}{ Heart rate } & $\mathrm{O}$ & 80 & 15 & $-14^{\star}$ & $-17 \cdot 5^{\star}$ \\
\hline & $W_{1}$ & 107 & 12 & $-19 \star \star \star$ & $-17 \cdot 8 \star \star \star \star$ \\
\hline & $W_{2}^{2}$ & 151 & 16 & $-36^{\star \star \star}$ & $-23 \cdot 8^{\star \star \star}$ \\
\hline & $R$ & $17 \cdot 9$ & $7 \cdot 1$ & $-2 \cdot 6$ & $-14 \cdot 5$ \\
\hline$\dot{V}_{E}(1 / \min$ & O & $21 \cdot 3$ & $9 \cdot 4$ & $-4 \cdot 5^{\star}$ & $-21 \cdot 1 \star$ \\
\hline \multirow[t]{3}{*}{ BTPS) } & $\mathrm{W}_{1}$ & $49 \cdot 6$ & $7 \cdot 8$ & $-5 \cdot 7 \star$ & $-11 \cdot 5^{\star}$ \\
\hline & $W_{2}$ & $87 \cdot 7$ & $26 \cdot 0$ & $-2 \cdot 8$ & $-3 \cdot 2$ \\
\hline & $\mathbf{R}$ & 0.31 & 0.04 & -0.01 & $-3 \cdot 2$ \\
\hline \multirow{4}{*}{$\begin{array}{c}\mathrm{Vo}_{2}(1 / \mathrm{min} \\
\mathrm{STPD})\end{array}$} & $\mathrm{O}$ & 0.37 & 0.08 & $-0.06^{\star}$ & $-16 \cdot 2 \star$ \\
\hline & $W_{1}$ & $1 \cdot 19$ & 0.15 & -0.06 & $-5 \cdot 0$ \\
\hline & $W_{2}$ & 1.97 & $0 \cdot 17$ & $0 \cdot 11$ & $5 \cdot 6$ \\
\hline & $\mathbf{R}$ & $39 \cdot 3$ & $7 \cdot 2$ & $10 \cdot 3 \star \star$ & 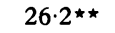 \\
\hline \multirow{4}{*}{$\begin{array}{l}\mathrm{AVO}_{2} \text { diff. } \\
(\mathrm{ml} / \mathrm{l})\end{array}$} & 0 & $53 \cdot 4$ & 11.9 & $22 \cdot 7 \star \star \star$ & $42 \cdot 5^{\star \star \star}$ \\
\hline & $\mathrm{W}_{1}$ & $76 \cdot 4$ & $18 \cdot 2$ & $49 \cdot 7 \star \star \star$ & $65 \cdot 1^{\star \star \star}$ \\
\hline & $\mathrm{W}_{2}$ & $94 \cdot 3$ & $23 \cdot 5$ & $61 \cdot 7 \star \star \star$ & $65 \cdot 4^{\star \star \star}$ \\
\hline & $\mathbf{R}$ & $8 \cdot 7$ & 1.9 & $-2 \cdot 0 \star \star$ & $-23 \cdot 4^{\star \star}$ \\
\hline \multirow[t]{4}{*}{$\mathrm{CO}(1 / \mathrm{min})$} & 0 & $7 \cdot 2$ & $2 \cdot 1$ & $-2 \cdot 7 \star \star$ & $-38 \cdot 0 \star \star$ \\
\hline & $W_{1}$ & $16 \cdot 2$ & $3 \cdot 6$ & $-7 \cdot 1 \star \star \star \star$ & $-43 \cdot 8^{\star \star \star}$ \\
\hline & $\mathrm{W}_{2}$ & $21 \cdot 6$ & $4 \cdot 0$ & $-8 \cdot 5^{\star \star \star}$ & $-39 \cdot 4 \star \star \star$ \\
\hline & $\mathbf{R}$ & 116 & 30 & $-19 \star$ & $-16 \cdot 4^{\star}$ \\
\hline \multirow[t]{4}{*}{$\mathrm{SV}(\mathrm{ml})$} & O & 91 & 22 & $-22^{\star}$ & $-24 \cdot 2^{\star}$ \\
\hline & $W_{1}$ & 151 & 27 & $-46^{\star \star}$ & $-30 \cdot 5^{\star \star}$ \\
\hline & $W_{2}$ & 145 & 33 & $-28 * \star$ & $-19 \cdot 3 \star \star$ \\
\hline & $\mathbf{R}$ & 0.98 & 0.44 & $0 \cdot 12$ & $12 \cdot 2$ \\
\hline \multirow{3}{*}{$\begin{array}{l}\text { Lactate } \\
\quad(\mathrm{mmol} / \mathrm{l})\end{array}$} & $\mathrm{O}$ & 0.96 & 0.42 & $0 \cdot 19$ & $19 \cdot 8$ \\
\hline & $W_{1}$ & 2.06 & 0.71 & 0.65 & $31 \cdot 6$ \\
\hline & $W_{2}$ & $4 \cdot 19$ & 1.66 & $0.92^{\star \star}$ & $22 \cdot 0 \star \star$ \\
\hline
\end{tabular}

Means and standard deviations (SD) of some circulatory and respiratory variables before and their mean (D) and percentage $(\bar{D} \%)$ changes after 13 months of antihypertensive treatment at rest in supine (R) and upright $(O)$ position and during exercise at two different work loads $\left(W_{1}=75 \mathrm{~W}\right.$; $\left.\mathrm{W}_{2}=150 \mathrm{~W}\right)$. Asterisks denote level of statistical significance:

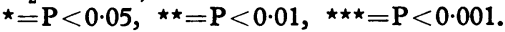

position and during exercise $(\mathrm{P}<0.001)$. This was partly the result of a similar decrease of the stroke volume ranging between 16 per cent at rest and 30 per cent during exercise $\left(\mathrm{W}_{2}\right)$. The relative decrease in both cardiac output and stroke volume was most pronounced during exercise at the lower level.

Inversely to the changes of cardiac output the arterio-mixed venous oxygen difference was much higher after treatment, the increase ranging between 26 per cent $(P<0.01)$ at rest and 65 per cent $(P<0.001)$ during exercise.

Both before and after treatment total systemic vascular resistance was only slightly raised in comparison with normotensives; after treatment, it was not significantly changed at rest in the supine, but higher in the upright position $(45 \%, P<0.05)$ and during exercise $\left(53\right.$ and $35 \%, P<0.01$, at $W_{1}$ and $\mathrm{W}_{2}$, respectively). Post-treatment pulmonary vascular resistance was higher under all conditions.

There was a general tendency towards higher arteriai lactic acid concentrations after treatment; the 
increase being about 20 per cent during $W_{2}$ $(\mathbf{P}<0.01)$.

\section{Discussion}

Treatment with oxprenolol for an average duration of 13 months, supplemented by hydrallazine during the last 6 months, had a distinct antihypertensive effect both at rest and during exercise, inducing a fall in arterial mean pressures by $14 \mathrm{mmHg}$ at rest and by 19 and $29 \mathrm{mmHg}$ during exercise at loads $W_{1}$ (oxygen uptake $1 \cdot 2 \pm 0 \cdot 2 \mathrm{l} / \mathrm{min}$ ) and $\mathrm{W}_{2}$ (oxygen uptake $2 \cdot 0 \pm 0 \cdot 2 \mathrm{l} / \mathrm{min}$ ) respectively. In the erect posture the average systolic pressure was $20 \mathrm{mmHg}$ lower after treatment; the decreases observed in mean and diastolic pressures were at borderline statistical significance.

The mode of antihypertensive action was similar at rest and during exercise: blood pressure was lowered by a reduction of cardiac output, while the systemic vascular resistance was mainly unchanged at rest in the supine position, but higher in the upright posture and during exercise. The relative reduction of cardiac output was most pronounced during work at the lower load $\left(\mathrm{W}_{1}\right)$ at which it corresponded to 44 per cent of the pretreatment level. Both a decrease of stroke volume by maximally 30 per cent $\left(W_{1}\right)$ and of heart rate by maximally 24 per cent $\left(W_{2}\right)$ contributed to the reduction of cardiac output. These changes towards a more hypokinetic pattern of circulation were accompanied by a significant increase of the arterio-mixed venous oxygen $\left(A-\nabla O_{2}\right)$ difference. During exercise at load $\mathrm{W}_{2}$ the $\mathrm{A}-\nabla \mathrm{O}_{2}$ difference rose from 94 to as much as $155 \mathrm{ml} \mathrm{O} / 1$ blood. This type of haemodynamic adaptation is typical of that observed during the action of adrenergic beta-receptor blockers; it has also been reported for other agents interfering with sympathetic nervous activity, such as clonidine (Koch, 1971b) which mainly inhibits the sympathetic vasomotor centre, or the ganglion blocking agent guanethidine (Sannerstedt and Conway, 1970).

Haemodynamic observations after prolonged treatment with adrenergic beta blocker agents are, however, scanty and mainly confined to resting conditions and relatively short periods; in only one study did duration of treatment apparently exceed 12 months (Tarazi and Dustan, 1972). While all studies have shown the typical reduction of heart rate, blood pressure, stroke volume, and cardiac output and the increase of the $\mathrm{A}-\nabla \mathrm{O}_{2}$ difference (Frohlich et al., 1968; Eisalo, Luomanmäki, and Heikkilä, 1969; Taylor et al., 1970; Majid et al., 1970; Sannerstedt et al., 1972; Tarazi and Dustan, 1972; Hansson et al., 1974), the results are con- tradictory with respect to the effect on systemic vascular resistance. Vascular resistance regularly increases in the acute experiment and in the early stage of treatment with a beta-receptor blocking agent (Sannerstedt, 1974). While earlier observations indicated that this rise in resistance persisted during long-term treatment (Frohlich et al., 1968), recent findings suggest that it may return to initial or even lower levels during prolonged treatment in spite of sustained reduction of blood pressure and cardiac output (Tarazi and Dustan, 1972; Hansson et al., 1974). Resetting of the baroreceptors in response to chronic reduction of cardiac output (Tarazi and Dustan, 1972) and/or adaptation changes in the blood vessel calibre (Brunner, 1974) have been thought to be responsible for this change in vascular resistance. In the present study, systemic vascular resistance increased in 9 and decreased in 4 patients at rest in the recumbent position, but it increased in all patients in the upright posture and during exercise. Despite a drastic reduction of cardiac output and a duration of treatment exceeding one year, and in spite of the additional use of the vasodilator hydrallazine, the results of the present study thus do not give evidence of such a readjustment of the vascular resistance occurring, at least not as far as conditions at rest in the erect posture and during exercise are concerned.

The patients included in the present study corresponded mainly to stage 1 to 2 hypertension according to the W.H.O. classification (1959); roughly 50 per cent of them were only moderately hypertensive and their pretreatment cardiac outputs showed a surprisingly hyperkinetic pattern of circulation: $8.7 \pm 1.7$ and $21.6 \pm 4.01 / \mathrm{min}$ corresponding to cardiac indices of $4 \cdot 0 \pm 0.9$ and $10 \cdot 7 \pm$ $2 \cdot 01 / \mathrm{min} \times \mathrm{m}^{2}$ at rest and during $\mathrm{W}_{2}$, respectively. Correspondingly, their $\mathrm{A}-\nabla \mathrm{O}_{2}$ differences were low, and the systemic vascular resistance was only moderately raised. This degree of hyperdynamic circulation is unusual for hypertensives of this age group and has probably largely contributed to the pronounced effects of treatment observed on cardiac output, the $\mathrm{A}-\nabla \mathrm{O}_{2}$ difference and on the calculated vascular resistance. It is established that the cardiac output lowering effect of beta-receptor blockade is most pronounced in hyperkinetic states (Sannerstedt, 1974).

However, the degree of reduction of cardiac output in the present study is still more surprising in view of the additional treatment with the peripheral vasodilator hydrallazine. From acute experiments (Brunner et al., 1967; Sannerstedt et al., 1971,1972 ) one should expect an attenuation or reversal of the cardiac output reducing effect and a 
decrease of vascular resistance. Using a dye dilution technique, Sannerstedt (1974) actually found this trend of haemodynamic readjustment after addition of hydrallazine to alprenolol in 3 hypertensive patients at rest; treatment with alprenolol had lasted for one month and combined treatment with additional hydrallazine for another 2 to 5 months. The results obtained in the present study at rest in the supine position are consistent with these observations, but the data obtained in the upright posture and particularly during exercise suggest that the vasodilator haemodynamic action of hydrallazine under these conditions is highly, if not entirely, overshadowed by that of the beta-receptor blocking agent. This simply implies that the betareceptor blockade obtained with the dose of oxprenolol was efficient enough not only to control the hyperdynamic circulation of these patients but also to inhibit the hydrallazine-induced baroreflex mechanism.

Our knowledge of the effect of antihypertensive drugs on the pulmonary circulation is still more limited. It is generally agreed that alpha- and betareceptor mediated vasomotor effects do not play a substantial role in the regulation of the pulmonary circulation and that pressure changes in the systemic arterial circulation have very little effect on the low pressure system of the pulmonary circulation (Gauer, 1972). In the present study pulmonary arterial pressures rose slightly at rest in the recumbent position and during exercise, and were unchanged in the upright position. Because of the substantial reduction of cardiac output, however, the calculated pulmonary vascular resistance was higher in all instances. These findings are at variance with the observation of insignificantly changed pulmonary pressures and resistances at rest and during moderate exercise after a 12-week oral administration of oxprenolol in the series of Taylor et al. (1970). However, this discrepancy might be entirely the result of the small number of patients (6) in the latter series. Clonidine (Koch, 1971b), which apparently inhibits the sympathetic vasomotor centre, and $\mathrm{AH}$ 5158, a combined alpha- and beta-receptor blocking agent (Koch, 1976), lacked the pressure raising effect on the pulmonary circulation at least in the acute experiment.

The pulmonary artery diastolic pressure has been shown (Forsberg, 1971) to reflect pulmonary wedge and thus left ventricular filling pressures in the absence of significant increases in pulmonary vascular resistance. Though the use of left ventricular filling pressure as a method of evaluating myocardial contractility is crude and insensitive, the absence of any pressure rise at rest both in the recumbent and the erect posture suggests that oxprenolol, at least in the combination with hydrallazine lacks significant negative inotropic effects at rest; but this effect is measurable during work and apparently increases with the work load. An increase of exercise pulmonary wedge pressure of a similar magnitude was observed after oral oxprenolol by Taylor et al. (1970). In this series, however, the effect of oxprenolol on pulmonary artery pressures and resistances and on pulmonary wedge pressure was less pronounced than that of propranolol. This supports the concept that oxprenolol does possess direct cardiostimulating properties besides its beta-receptor blocking action. The finding of an increased left ventricular filling pressure during long-term oral oxprenolol treatment during exercise but not at rest in the present study is consistent with this concept since the direct cardiostimulating action is known to be most effective at rest.

\section{References}

Áblad, B. (1963). A study of the mechanism of the hemodynamic effects of hydrallazine in man. Acta Pharmacologica et Toxicologica, 20, Suppl. 1.

Bengtsson, C. (1974). Long-term effect of alprenolol as antihypertensive agent. Acta Medica Scandinavica, Suppl. 554, 9.

Berglund, G., and Hansson, L. (1971). Hypertension therapy with propanolol and hydrallazine. (In Swedish.) Lakartidningen, 68, 5009.

Brunner, H. (1974). The antihypertensive effect of betablockers. In Beta-blockers-Present Status and Future Prospects, p. 19. Ed. by W. Schweizer. Hans Huber, Berne.

Brunner, H., Hedwall, P. R., and Meier, M. (1967). Influence of adrenergic beta-receptor blockade on the acute cardiovascular effects of hydrallazine. British fournal of Pharmacology and Chemotherapy, 30, 123.

Dollery, C. T., Paterson, J. W., and Conolly, M. E. (1969). Clinical pharmacology of $\beta$-receptor-blocking drugs. Clinical Pharmacology and Therapeutics, 10, 765.

Eisalo, A., Heino, A., and Munter, J. (1974). The effect of alprenolol in elderly patients with raised blood pressure. Acta Medica Scandinavica, Suppl. 554, 23.

Eisalo, A., Luomanmäki, K., and Heikkilä, J. (1969). Haemodynamic effects of Trasicor, a new beta-adrenergic blocking agent, in hypertensive patients. Acta Medica Scandinavica, 186, 105.

Forsberg, S. A. (1971). Relations between pressure in pulmonary artery, left atrium, and left ventricle with special reference to events at end of diastole. British Heart fournal, 33, 494.

Freeman, J. W., and Knight, L. W. (1975). Oxprenolol and hydrallazine in the treatment of hypertension. Medical fournal of Australia, Suppl. 1, 12.

Frohlich, E. D., Tarazi, R. C., Dustan, H. P., and Page, I. H. (1968). The paradox of beta-adrenergic blockade in hypertension. Circulation, 37, 417.

Gauer, O. H. (1972). Kreislauf des Blutes. In Physiologie des Menschen, Bd. 3, Herz und Kreislauf, p. 269. Ed. by O. $\mathrm{H}$. Gauer, K. Kramer, and R. Jung. Urban and Schwarzenberg, Munich, Berlin, and Vienna. 
Hansson, L., and Werkö, L. (1975). Treatment of hypertension with beta blocking agents. (In Swedish.) Lakartidningen, 72, 959.

Hansson, L., Zweifler, A. J., Julius, S., and Hunyor, S. N. (1974). Hemodynamic effects of acute and prolonged beta-adrenergic blockade in essential hypertension. Acta Medica Scandinavica, 196, 27.

Hohorst, H. J. (1963). L-(t)-lactate. Determination with lactic dehydrogenase and D.P.N. In Methods of Enzymatic Analysis, p. 67. Ed. by H. U. Bergmeyer. Verlag Chemie, Weinheim; Academic Press, New York.

Holmgren, A., and Pernow, B. (1959). Spectrophotometric measurement of oxygen saturation of blood in the determination of cardiac output. A comparison with the Van Slyke method. Scandinavian fournal of Clinical and Laboratory Investigation, 11, 143.

Jacobsson, K. A., Koch, G., Levander-Lindgren, M., and Michaelsson, G. (1966). Double blind trial with prenylamine (Segontin) in coronary insufficiency. Acta Medica Scandinavica, 180, 126.

Johnsson, G., de Guzman, M., Bergman, H., and Sannerstedt R. (1969). The hemodynamic effects of alprenolol and propranolol at rest and during exercise in hypertensive patients. Pharmacologia Clinica, 2, 34.

Johnston, C. I. (1975). Pathophysiological rationale for the use of vasodilators in hypertension. Medical fournal of Australia, Suppl. 1, 3.

Katila, M., and Frick, M. H. (1970). Combined dihydralazine and propranolol in the treatment of hypertension. Internationale Zeitschrift für Klinische Pharmakologie, Therapie und Toxikologie, 4, 111.

Koch, G. (1968). Lung function and acid-base balance in the newborn infant. Acta Paediatrica Scandinavica, Suppl. 181.

Koch, G. (1971a). Simplified method for percutaneous arterial catheterisation. Lancet, 1, 1166.

Koch, G. (1971b). Hemodynamic effects of 2-(2.6-dichlorophenylamino)-2-imidazoline hydrochloride (ST 155) at rest and during exercise with special respect to the pulmonary circulation. Arzneimittel-Forschung, 21, 57.

Koch, G. (1976). Acute hemodynamic effects of an alpha- and beta-receptor blocking agent (AH 5158) on the systemic and pulmonary circulation at rest and during exercise in hypertensive patients. American Heart fournal. In the press.

Larsson, H., and Kjellberg, S. R. (1948). Röntgenological heart volume determination with special regard to pulse rate and the position of the body. Acta Radiologica, 29, 159

Lund-Johansen, P. (1967). Hemodynamics in early essential hypertension. Acta Medica Scandinavica, Suppl. 482.

Majid, P. A., Sharma, B., Saxton, C., Stoker, J. B., and Taylor, S. H. (1970). Haemodynamic effects of oxprenolol in hypertensive patients. Postgraduate Medical fournal, 46, November Suppl., 67.

Prichard, B. N. C., and Gillam, P. M. S. (1966). Propranolol in hypertension. American fournal of Cardiology, 18, 387.

Prichard, B. N. C., and Gillam, P. M. S. (1969). Treatment of hypertension with propranolol. British Medical fournal, $1,7$.

Sannerstedt, R. (1974). Selection of hypertensive patients for treatment with beta-blockers alone or in combination. In Beta-blockers-Present Status and Future Prospects, p. 51. Ed. by W. Schweizer. Hans Huber, Berne.

Sannerstedt, R., and Conway, J. (1970). Hemodynamic and vascular responses to antihypertensive treatment with adrenergic blocking agents: a review. American Heart fournal, 79, 122.

Sannerstedt, R., Stenberg, J., Johnsson, G., and Werkö, L. (1971). Hemodynamic interference of alprenolol with dihydralazine in normal and hypertensive man. American Fournal of Cardiology, 28, 316.

Sannerstedt, R., Stenberg, J., Vedin, A., Wilhelmsson, C., and Werkö, L. (1972). Chronic beta adrenergic blockade in arterial hypertension. Hemodynamic influences of dihydralazine and dynamic exercise and clinical effects of combined treatment. American fournal of Cardiology, 29, 718.

Scholander, P. F. (1947). Analyser for accurate estimation of respiratory gases in one-half cubic centimeter samples. fournal of Biological Chemistry, 167, 235.

Snedecor, G. W. (1967). Statistical Methods, 6th ed. Iowa State University Press, Ames, Iowa.

Tarazi, R. C., and Dustan, H. P. (1972). Beta adrenergic blockade in hypertension: practical and theoretical implications of long-term hemodynamic variations. American Fournal of Cardiology, 29, 633.

Taylor, S. H., Majid, P. A., Saxton, C., and Stoker, J. B (1970). Comparison of the circulatory effects of oxprenolol and propranolol in hypertensive patients. In Betaadrenergic Receptor Blocking Drugs, p. 47. Ed. by F. O. Simpson. Published for CIBA Laboratories Ltd., by Australia Drug Information Services PTY. Ltd.

Werkö, L. (1971). Leading article: new treatment for hypertension. European fournal of Clinical Pharmacology, 3, 61 .

W.H.O. (1959). Prevention and control of arterial hypertension. World Health Organization Technical Report Series, 168, 4.

Zacest, R. (1975). The clinical pharmacology of hypotensive vasodilator drugs. Medical fournal of Australia, Suppl. $1,4$.

Zacest, R., Gilmore, E., and Koch-Weser, J. (1972). Treatment of essential hypertension with combined vasodilation and beta-adrenergic blockade. New England fournal of Medicine, 286, 617.

Requests for reprints to Professor G. Koch, Department of Physiology, Freie Universität Berlin, Arnimallee 22, D-1 Berlin 33 (WestBerlin), Germany. 